\title{
International Equity Markets Co-movements And Contagion: A Novel Perspective
}

\author{
Olfa Kaabia, Assistant Professor, INSIGNIS Group INSEEC, Paris, France
}

\begin{abstract}
Our paper conducts an asset pricing perspective to investigate OECD equity markets comovements and contagion during different crises. The paper aims at distinguishing between changes in cross-markets linkages during a crisis, on the one hand, and strong but stable crossmarkets linkages and permanent shifts in these linkages, on the other hand. Our empirical setting relies on the three factor model of Bekeart and al. (2005, 2011) and differs by testing the comovements in their double dimensions: interdependence and contagion during the Asian, the European Exchange Rate Mechanism (ERM) and the Global Financial crises in different regions. Our results highlight the existence of cross-sectional patterns both in regional and USA market correlations with OECD equity markets. Evidence of contagion exists during the ERM and the Global Financial crisis, but no contagion caused by the Asian crisis. Our findings lead to an international diversification opportunity and suggest that contagion effects are not strongly related to high levels of global integration.
\end{abstract}

Keywords: Co-movements and Contagion; Global Financial Crises; OECD Equity Markets; International Equity Markets

\section{INTRODUCTION}

(๑)

ne of the salient consequences of globalization and the rapid transmission of information across countries was the change of the structure of stock markets, which showed substantial growth in size and level. Another result is that the last two decades have been marked by numerous financial crises in the OECD countries: the European Exchange-Rate Mechanism (ERM henceforth) crisis (1992-1993), the Asian crisis (1997-1998), the dot-com crisis (2000), the subprime mortgages crisis (2007) followed by the actual Global Financial Crisis (GFC henceforth).

Thus, the contagion phenomenon is not a new topic, however, what is surprising is that shocks originating in a particular nation affect, in a very severe and unexpected way, countries that are very distant and that appear to be largely unrelated to the shock originator as the transmission of turmoil from Hong Kong to Mexico and Chile in 1997. Many fears appeared because a local crisis that starts in a country spreads out to near or even far economies becoming an international crisis. Hence, understanding the origins and dynamics of propagation is paramount in equity markets especially when considering investment strategies in an international portfolio context. Let consider the subprime crisis, it initially had its origin in the U.S. in a relatively small segment of the lending market, the subprime mortgage market, it rapidly spread across virtually all economies, both advanced and emerging, as well as across economic sectors. It also affected equity markets worldwide, with many countries experiencing even sharper equity market crashes than the U.S., making it an ideal laboratory to revisit the debate about the presence and sources of "contagion" in equity markets.

The discussion of cross-markets transmission mechanism is well established and documented in the literature; however, there is some misunderstanding between some concepts such as spillover effects, co-movements and contagion. Consequently, it seems more useful to restrict the term of contagion to those situations where the extent and magnitude to which a shock is transmitted internationally exceeds what was expected ex-ante and therefore, distinguish it from market linkages and excess co-movements in stock market prices. Unfortunately, the 
definition of contagion is still not unanimous among the economists. ${ }^{1}$ Along with the various studies on different crises, the literature can bring to light two main distinctions: "pure contagion" (also known as true contagion, shiftcontagion, or even market-based contagion) and interdependencies (also called spillovers and fundamentals-based contagion). More precisely, interdependence is defined as the relationship that exists between asset classes on average over the sample period; whereas, contagion is defined as a change in the transmission mechanism between assets in crisis periods.

Many theoretical and empirical studied these notions, nevertheless, by construction, the tested models cannot, in general, clearly distinguish between interdependence and contagion in global and regional stock markets. ${ }^{2}$ The results of these studies are hybrids and do not lead to convincing conclusions. For example, if the work of Kamisnsky and Reinhart (2001) and Nagayasu (2000) concluded to the existence of contagion between emerging countries, however, Forbes and Rigobon (2002), and Billio and Pelizzon ${ }^{3}$ (2003) questioned the existence of contagion and explained the co-movements of the markets just by their interdependencies.

Based on this distinction, Bekaert et al. (2005) develop a model to identify economic fundamentals (such as the systematic sources of risk) from the residual correlations, which are used to test directly the existence and dynamics of contagion. They find no evidence in favor of contagion during the Mexican crisis, but show that the Asian crisis was characterized by large movements of contagion. Also, Dungey et $a l .{ }^{4}(2003,2007)$ study contagion in Asia and Australia and get similar results. Chiang et al. (2007) use a Dynamic Conditional Correlation GARCH model to test contagion between nine Asian stock returns from 1990 to 2003. They use dummy variables to delimit their sample in three periods, and for each period, they observe the correlation dynamic between selected stock markets. More recently, there is a growing body of empirical literature testing for financial contagion during the GFC. In that sense Longstaff and Ang (2011) study the exposure of sovereigns to systemic shocks, in the USA and $\mathrm{EU}$ and find that sovereign risk is strongly and negatively correlated with stock market indexes. Bekaert et al. (2011) analyze contagion across different portfolios of equity markets of 55 countries during the 2007-09 financial crisis. Using a CAPM, they find systematic and substantial contagion from domestic equity markets to individual domestic equity portfolios, with its severity inversely related to the quality of countries' economic fundamentals. Therefore, they conclude that investors focus substantially more on country-specific characteristics (idiosyncratic risks) during the crisis period.

Other articles focus on the drivers of transmission of a crisis across firms and markets within the U.S., such as Tong and Wei (2010), and Diebold and Yilmaz (2010), or articles taking a more macroeconomic perspective such as Eichengreen et al. (2012), Frankel and Saravelos (2010) and Rose and Spiegel (2010, 2011). Some of other articles tackle the issue of market contagion and specifically asset markets. Among them Guo et al. (2011) and Longstaff (2010) study the cross-asset contagion between several asset classes in the US market. Kenourgios et al. (2011) deal with the contagion in the BRIC emerging equity markets. Johansson (2011) examines equity market movements in East Asia and Europe during the GFC. Neaime (2012) examined the impact of the GFC in the MENA region, he found a higher correlation with the U.S. stock market during the crisis. Hau and Lai (2012) show that stocks with a high share of equity funds ownership performed relatively well during the GFC, whereas stocks with ownership links to funds that were heavily affected by portfolio losses in financial stocks severely underperform. Beltratti and Stulz (2012) investigate whether the variation in the cross-section of stock returns of large banks across the world during the crisis is related to bank-level governance, country-level governance, country-level regulation, as well as to bank balance sheet and profitability characteristics before the GFC. Calomiris et al. (2012) show that credit supply shocks, global demand shocks and selling pressures in the equity market had a significant negative effect on individual stock returns during the GFC but had no such effects.

Almeida et al. (2012) find that firms with large portions of long-term debt maturing at the time of the GFC reduced investment significantly more than similar firms that did not need to refinance their debt during the crisis.

\footnotetext{
${ }^{1}$ For more details, see, among others, Rigobon (1999), Forbes and Rigobon (2000, 2002), Jang and Sul (2002), Claessens et al. (2002) and Corestti et al. (2005).

${ }^{2}$ See King and Wadhwani (1990).

${ }^{3}$ They define contagion as the change in the transmission mechanisms that takes place during a turmoil period (...) inferred by a significant increase in the cross-market correlation.

${ }^{4}$ The authors propose a synthesis of theoretical and empirical works on international financial contagion.
} 
The literature review identifies an emerging need to conduct further research on the topic as the very issue is lacking the requisite evidence. An important question is whether this increased co-movements of global financial markets during past crises provides evidence of contagion. In this paper, we offer a pass at filling this issue of the literature. Motivated by the above discussion, the novelty of our analysis is to distinguish clearly the calm from the turbulent period when studying the increase of the unexpected returns. So, the aim of this paper is to compare our results to those of Bekaert et al. $(2005,2011)$ who use a dummy variable to account for crisis period. We develop a different procedure by adding two dummy variables to consider both turmoil and calm periods. Thus, we consider that the comovements unexplained by fundamentals are signs of contagion in normal and crisis periods.

This paper studies the changes in the dynamics of conditional correlation of stock market returns of 16 OECD countries both in the times and in the tranquil period. The main questions addressed are: Has there been contagion in OECD equity markets during the Asian crisis, the ERM, or even the GFC one? If so, did contagion primarily emanate from the USA or from a specific region? Dealing with a three-factor model with time-varying betas, we extract the unexpected returns of sixteen OECD stock markets in three regions: Europe, Asia-Pacific, and North America. To this proposition, we estimate time-varying betas using rolling regressions and test the appropriate GARCH-type model to capture the (a)symmetries in volatility, ${ }^{5}$ which is highly desirable when the topics of contagion and interdependence are studied. Once extracted, the residual correlations are introduced in a panel model by adding dummy variables to account for both tranquil and crisis periods to test contagion.

Our analysis is particularly relevant in focusing on a country's vulnerability to externally originated shocks from local, regional and USA risks both in tranquil and crisis periods. Our study is useful for both investors and policy makers to counter the negative impacts effects during calm and crisis periods. In fact, if OECD equity markets are contagious, economic policy should focus on structural reforms ensuring a stable domestic market, in order to limit, even stop, the amplification of shocks between stock markets since it is well-known that the dynamics of international stock markets share common features, and influence one another. Moreover, distinction between interdependency and contagion has important implications for researchers, investors and policy makers. Since, investors use correlations as input for portfolio diversification and selection, if the correlations are estimated in times of tranquility and used in the crisis periods, this could generate unpredictable consequences. Similarly, policy makers need to distinguish transmission of shocks to domestic economies between tranquil and crisis period. Decision making (policy responses and contingency plans) during crisis period, on the basis of the study of transmission of shocks during tranquil period, could yield serious consequences for the domestic economies. Our work relates to the growing literature on the global financial crises and to the best of our knowledge, no paper in the contagion literature has proposed such a methodology to test and model contagion effects in OECD equity markets.

The main results of our study are as following. First, cross-sectional patterns exist both in regional and USA market correlations with OECD equity markets, however, differences in vulnerability exist. Indeed, the idiosyncratic residuals are better correlated with the US even in a tranquil period. Second, the hypothesis of no contagion over the entire period, for the USA, can be rejected for most of the OECD markets with different magnitudes. The additional correlation of the country's idiosyncratic shocks with the USA during the GFC period is positive indicating that residuals have become more correlated during the crisis. Third, European countries such as Germany, the UK, the Netherlands, Spain and Italy are the most significantly affected by the ERM crisis. Nevertheless, during the Asian crisis, there is a no regional contagion. Fourth, contagion effects are not strongly related to high levels of global integration.

The rest of the paper is structured as follows: Section 2 presents the theoretical framework. Section 3 exposes the empirical study. Section 4 deals with the results and interpretations. Section 5 draws the appropriate conclusions.

\footnotetext{
${ }^{5}$ Inspired by the results of Bakshi et al. (1997), Bekaert and Harvey (1997), and $\mathrm{Ng}$ (2000), we model the error terms using a type-GARCH model in order to well characterize the stylized facts of the variance in the OECD stock returns.
} 


\section{THEORETICAL FRAMEWORK}

This section outlines the models we estimate, contrasts the concepts of correlation versus contagion, and explains the estimation process.

\section{Model To Capture Unexpected Returns}

We assume that the PPP is verified ${ }^{6}$ and build on the results of Bekaert and Harvey $(2005,2011)$ by retaining a three-factor model based on the Capital Assets Pricing Model (CAPM) framework. Our model simultaneously considers local sources in addition to global and regional risk factors.

In addition, we assume that the portfolio of the USA market is a good benchmark of the global market within a portfolio of regional market and local sources of risks as follows:

$$
\begin{aligned}
& i_{i, t}=Z_{i, t 1}+\underset{i, t 1}{U S} U_{U S, t 1}+{ }_{i, t 1}^{r e g} \operatorname{reg,t1}+{ }_{i, t 1}^{U S} e_{U S, t}+{ }_{i, t 1}^{r e g} e_{r e g, t}+e_{i, t} \\
& e_{i, t} \mid \quad t_{1} \sim N\left(0, \quad \begin{array}{cc}
2 \\
i, t
\end{array}\right)
\end{aligned}
$$

where the conditional expected excess returns for the country $i$, the USA and regional markets are respectively,

$$
{ }_{i, t}=E\left(R_{i, t} /_{t 1}\right) \quad R_{f, t} ; \quad U S, t 1=E\left(\left(R_{U S, t} /_{t 1}\right) R_{f, t}\right) \text { and } \quad r_{r e g, t 1}=E\left(\left(R_{r e g, t} / t_{t 1}\right) R_{f, t}\right) \text { that are expressed }
$$

in US dollars with $R_{i, t}, R_{U S, t}$ and $R_{\text {reg }, t}$ are, correspondingly, the returns in US dollar of the market $i$, the USA and the regional markets.

${ }_{t}$ includes all the information available at time $\mathrm{t} 1 . R_{f, t}$ is the risk-free rate. $e_{U S, t}$ and $e_{U S, t}$ are, respectively, the unanticipated returns of the global market and the regional one. $e_{i, t}$ is the residual of the estimated model for the market $i ; Z_{i, t}$ is the set of local information variables available until the date $\mathrm{t}-1$, including a constant, and ${ }_{i}$ is the vector of coefficients to be estimated. Also, $\quad \underset{i, t 1}{U S}$ and $\underset{i, t 1}{r e g}$ are the sensitivities of the market $i$ to the USA market and the regional one.

To account for the stylized fact that the variance of the idiosyncratic return shock of market $i$ is conditional and asymmetric, we assume that the error term of the Eq. (2) are modeled using a DCC-GJR-GARCH $(1,1)$ process. ${ }^{7}$ The latest captures any asymmetric effects in volatility and assumes that bad and good news have different effects on volatility: negative shocks are supposed to have a higher effect on stock return volatility compared to positive ones of the same scale. Moreover, Dungey and Zhumabekova (2001), and Corsetti et al. (2012) point out miss-specification issues and suggest using dynamic conditional correlation GARCH models when studying contagion.

\footnotetext{
${ }^{6}$ This is a simplifying assumption. We agree as Adler and Dumas (1983), Carrieri et al. (2007) and Tai (2007) that there are deviations from Purchasing Power Parity (PPP), and variations in consumption baskets across geographies.

Therefore, if PPP if not verified, any investment in a foreign asset is a combination of an investment in the performance of the foreign asset and an investment in the performance of the domestic currency relative to the foreign currency.

${ }^{7}$ The multivariate framework is more relevant than the bivariate one when considering the dynamic interactions and capturing the co-movements between the international returns (see Glosten, Jagannathan and Runkle (1993), and Bekaert et al. (2005)).
} 
Therefore, the DCC-GJR-GARCH $(1,1)$ model specified is:

$$
\begin{aligned}
& H_{t}=D_{t} R_{t} D_{t} \\
& D_{t}=\operatorname{diag}\left(\sqrt{h_{11, t}}, \sqrt{h_{22, t}}, \ldots, \sqrt{h_{n, n, t}}\right) \\
& R_{t}=\left(\begin{array}{lll}
1 & 1 & { }_{2}
\end{array}\right) R+{ }_{1} t_{1}+{ }_{2} R_{t 1}
\end{aligned}
$$

where $H_{t}$ is the variance matrix and $D_{t}$ is a diagonal matrix of conditional standard deviations for each of the return series, obtained from estimating a univariate GJR-GARCH ${ }^{8}$ process of Glosten et al. (1993) in the equation of variance expressed as :

$$
h_{i i, t}=w_{i}+\alpha_{i} \varepsilon_{i i, t-1}^{2}+\beta_{i} h_{i i, t-1}+\gamma_{i} I_{i, t} \varepsilon_{i i, t-1}^{2}
$$

The persistence is measured by the coefficients ${ }_{i} \&{ }_{i}$ and $I_{i, t}$ is an indicator function capturing asymmetry in the estimate of the coefficient ${ }_{i}$. For instance, a negative value of ${ }_{i}$ implies that negative residuals increase the variance more than positive residuals. $R$ is a symmetric $N \quad N$ positive definite parameter matrix of dynamic conditional correlations in which ${ }_{1}$ and ${ }_{2}$ are non-negative parameters satisfying ${ }_{1}+{ }_{2}<1$.

It is specified as Tse and Tsui (2002) GARCH model with ${ }_{t}$ is the $N \quad N$ correlation matrix of $\varepsilon_{\tau}$ for $=t \quad M, t \quad M+1, \ldots, t \quad 1$.

Its $i, j^{\text {th }}$ element is given by:

$$
\Psi_{i j, t-1}=\frac{\sum_{m=1}^{M} u_{i, t-m}, u_{j, t-m}}{\sqrt{\left(\sum_{m=1}^{M} u_{i, t-m}^{2}\right)\left(\sum_{m=1}^{M} u_{j, t-m}^{2}\right)}}
$$

where $u_{i, t}=\frac{i, t}{\sqrt{h_{i i, t}}}$. The matrix $\quad{ }_{t 1}$ can be expressed as ${ }_{t 1}=B_{t 1}{ }_{1}^{1} L_{t 1} L_{t 1}^{\prime} B_{t 1}{ }_{1}^{1}$ in which $L_{t 1}=\left(u_{t 1}, \ldots, u_{t M}\right)$ is a $N M$ matrix and $B_{t-1}$ is a $N \quad N$ diagonal matrix with $i^{t h}$ diagonal element given by $u_{h=1}^{2} h \quad$ and $u_{t}=\left(u_{1, t}, u_{2, t}, \ldots u_{N, t}\right)^{\prime}$

A necessary condition to measure the positivity of ${ }_{t}$, and therefore that of $R_{t}$ is $M N$. Then, $R_{t}$ is itself a correlation matrix if $R_{t 1}$ is also a correlation matrix ( ${ }_{i i}=1$ ). Moreover, the Eq. (1) can decompose the return of the market $i$ into an expected return and unexpected one. More clearly, the expected return is given by:

$$
\left.E \quad E_{i, t 1}\right|_{t 1}={ }_{i} Z_{i, t 1}+\underset{i, t 1}{U S} \quad \text { US, }, 1+\underset{i, t 1}{r e g} \text { reg,t } 1
$$

\footnotetext{
${ }^{8}$ This model gives better statistical results than the DCC-GARCH one.
} 
Thus, the unexpected portion of the market return is driven not only by shocks from the local market but also by two foreign shocks originating in the U.S. and the region risks given by:

$$
{ }_{i, t}={ }_{i, t 1}^{U S} e_{U S, t}+{ }_{i, t 1}^{r e g} e_{r e g, t}+e_{i, t}
$$

Also, following Bekaert et al. (2005, 2011), we conduct an analysis of the total variance in each of the studied markets. The expressions are derived by assuming that local shocks are uncorrelated across countries and that they similarly do not correlate with USA and regional markets.

Therefore, the variance of the market $i$ is given by:

$$
\left.h_{i, t}=E\left(\begin{array}{c}
2 \\
i, t
\end{array} \mid \begin{array}{ll}
t 1
\end{array}\right)=\left(\begin{array}{cc}
U S \\
i, t 1
\end{array}\right)^{2} \quad \underset{U S, t}{2}+\left(\begin{array}{c}
r e g \\
i, t 1
\end{array}\right)\right)^{2} \quad \underset{r e g, t}{2}+\underset{i, t}{2}
$$

Besides, we focus on the time variation and cross-sectional patterns, both in US and regional market correlations of market $i$ that are given by:

$$
\begin{aligned}
& i, u s, t=\frac{\begin{array}{l}
u s \\
i, t 1
\end{array} u_{s, t}}{\sqrt{h_{i, t}}}
\end{aligned}
$$

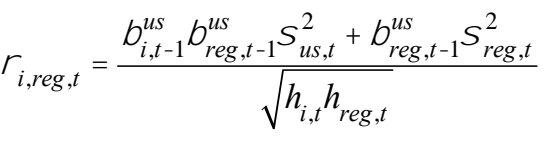

where $h_{r e g, t}=\left(\begin{array}{l}u s \\ r e g, t 1\end{array}\right)^{2} \underset{u s, t}{2}+\underset{r e g, t}{2}$ is the conditional variance of the regional market return.

Additionally, we analyze the shares of the total variance explained respectively by the global market $\left(V R_{i}^{U S}\right)$, and the regional one $\left(V R_{i}^{\mathrm{Re} g}\right)$, computed as follows:

$$
\begin{aligned}
V R_{i, t}^{U S} & =\frac{\left(\begin{array}{c}
U S \\
i, t 1
\end{array}\right)^{2}}{2} \begin{array}{l}
2 \\
h_{i, t}
\end{array} \\
h_{i, t} & \\
V R_{i, t}^{\operatorname{Reg}} & =\frac{\left(\begin{array}{c}
r e g \\
i, t 1
\end{array}\right)^{2} \begin{array}{l}
2 \\
r e g, t
\end{array}}{h_{i, t}}
\end{aligned}
$$

Those variance ratios are proportional to the increase of the "factor", variances.

This preliminary analysis is to investigate when returns are excessive as a pre-condition for detecting contagion effects.

\section{Model To Test Contagion}

In order to test contagious effects, we concentrate on measuring the correlation of the model's idiosyncratic shocks or unexpected returns in normal and crisis periods. We retain that significant increases in residual correlations are signs of contagion. These residual correlations are obviously corrected for heteroscedasticity as suggested by Forbes and Rigobon (2002).

${ }^{9}$ USA or regional. 
Our tests involve the time-series cross-section regression model:

$$
\begin{aligned}
\widehat{e}_{i, t} & ={ }_{i}+{ }_{i, t} \widehat{e}_{U S, t}+{ }_{i, t} \widehat{e}_{r e g, t}+u_{i, t} \\
& =p_{1} D_{i, t}^{1,1}+q_{1} D_{i, t}^{1,2} \\
& =p_{2} D_{i, t}^{2,1}+q_{2} D_{i, t}^{2,2}
\end{aligned}
$$

where $\widehat{e_{i, t}}, \widehat{e}_{U S, t}$ and $\widehat{e}_{r e g, t}$ are the estimated idiosyncratic return shocks of market $i$, US and region, respectively. ${ }^{10}$

$D_{i, t}^{1,1}, D_{i, t}^{1,2}, D_{i, t}^{2,1}$ and $D_{i, t}^{2,2}$ are dummy variables. More specifically, $D_{i, t}^{1,1}$ and $D_{i, t}^{2,1}$ denote for tranquil periods respectively in the USA and regional markets and take a value of one during tranquil periods and zero otherwise. Whereas, $D_{i, t}^{1,2}$ and $D_{i, t}^{2,2}$ represent turmoil periods both in the USA and regional markets, and so take the value of one during turbulent periods and that of zero otherwise. By adding tranquil versus crisis dummies, we distinguish the change in the time-varying beta coefficients during tranquil versus crisis periods. If there is evidence for such a change, this suggests signs of contagion effects; we call this phenomenon contagion.

Unlike Bekaert et al. $(2005,2011)$, we add two dummy variables to consider both turmoil and calm periods. Bekaert et al. $(2005,2011)$ assume that the coefficient $p$ accounts for the additional correlation in the whole period and that $q$ reflects the excess of correlation during the crisis period. Consequently, additional residuals correlations in crisis period is considered twice in $p$ and $q$ estimations. Thus, we assume that such estimation of the panel model leads to a redundancy in the parameter estimation. To avoid this issue, we propose to correct this estimation redundancy by testing the contagion separately both in calm and crisis periods.

Our model has the advantage of first, taking into account both turmoil and calm periods, and second, considering simultaneously the USA and regional risk factors. That being said, we are more interested in studying the time-series patterns during crisis periods than in tranquil periods. The hypothesis of contagion would be supported if the model's idiosyncratic shocks exhibit significant correlation during calm/ crisis periods. Thus, the test of significance of the parameter $q_{i} \quad i=1,2 \mathrm{can}$ be interpreted as a test of contagion in times of crisis. And the test of significance of the parameters $p_{1}$ and $p_{2}$ can be interpreted as a test of contagion over tranquil periods from USA/ regional markets.

\section{EMPIRICAL STUDY}

\section{Data}

Our dataset includes monthly Stock Market Indices for 17 OECD countries ${ }^{11}$ : S\&P 500 (USA), TSX (Canada), Helsinki General (Finland), CAC 40 (France), DAX 30 (Germany), ISEQ (Ireland), Milan MIB (Italy), AEX (Netherlands), Madrid General Index (Spain), KFX Copenhagen (Denmark), Oslo Stock Exchange (Norway), Stockholm Index (Sweden), Zurich Swiss Market Index (Switzerland), FTSE 100 (United Kingdom), All Ordinaries Index (Australia), Nikkei 225 (Japan), New Zealand Stock Exchange 50 (New-Zealand). Our sample covers the period from $01 / 01 / 1990$ to $01 / 11 / 2013$.

\footnotetext{
${ }^{10} \mathrm{We}$ assume that the regional and international contagion effects are not correlated in the equation 11.

${ }^{11}$ The selection of these countries is based on their size (in terms of gross domestic product, GDP) and their economic/market structure.
} 
Our dataset is drawn from Datastream and Morgan Stanley Capital International (MSCI). The stock market indices are taken with reinvestment of dividends and for each country, we compute their growth rates. ${ }^{12}$ We divide the considered OECD countries in three regions: North America (USA and Canada), Europe (Finland, Norway, Sweden, Denmark, Ireland, the U.K, France, the Netherlands, Germany, Switzerland, Italy, and Spain), and AsiaPacific (Japan, Australia and New-Zealand), and construct our own indices for each region. So, we compute the stock market index (representative of each of the three considered regions) as the geometric mean of stock returns weighted by stock market capitalization of each member country. When the market $i$ is studied, the regional index used is equal to the weighted average of all regional markets except the market $i$ as follows:

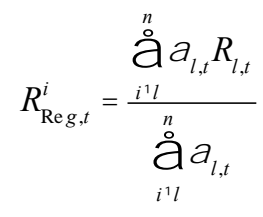

where $n$ is the number of markets in the region Reg and is the market capitalization. In our analysis, we first transform the series into returns, and then subtract from them the Eurodollar rate at one month (the risk-free rate) to get the excess returns. All data are expressed in US dollars. Equity returns are a useful basis for our analysis as they incorporate all available information on the expected future profitability of companies in a country, and therefore capture even expected changes in real indicators. Besides and as to capture the local sources, we include the dividend yield of the local market portfolio, inflation and real effective exchange rates indices in our database. These monthly data are also from 01/01/1990 to 01/11/2013 and are extracted from Datastream, Federal Reserve Bank of Saint Louis and Financial Statistics of the Federal Reserve Board.

\section{Statistical Properties}

The statistical properties for return series are summarized below in Table 1. It appears that Finland has the highest monthly returns of 0.305 followed by Sweden and Italy with respectively, 0.2487 and 0.2103 . However, Norway has the lowest returns with -0.3121. Finland experiences the highest risk level of $8.99 \%$ followed by Norway and Sweden with respectively, 6.89\% and 6.85\%. And Australia appears to be the least risky with $4.12 \%$. Skewness is negative in most cases, indicating that the tail on the left side is longer than the right one. For Kurtosis, the values exceed 3 denoting the non-normality of the return series which is confirmed by the Jarque-Bera test statistic (JB) that strongly rejects the hypothesis of normality, except for Italy.

Moreover, we report the unconditional correlations between the USA market, and the considered OECD stock returns. We can see that cross-market correlations of the USA and the OECD equity returns are positive and high indicating that the OECD equity markets move closely and are not disconnected from to the USA stock market. We also perform the Engle (1982) LM ARCH test to further analyze the distributional characteristics of stock return series. This test provides a clear indication of ARCH effects in the return series.

\footnotetext{
${ }^{12}$ Stock return, $r_{i, t}$, is computed as the logarithmic difference of closing stock price index, $P_{i, t}$ as follows: $r_{i, t}=\log \left(p_{i, t} / p_{i, t 1}\right) \quad 100$
} 
Table 1: Return Series Descriptive Statistics

\begin{tabular}{|c|c|c|c|c|c|c|c|c|c|c|}
\hline Stock Returns & Mean & Median & Maximum & Minimum & $\begin{array}{l}\text { Std } \\
\text { Dev }\end{array}$ & Skewness & Kurtosis & $\begin{array}{c}\text { Jarque } \\
\text { Bera }\end{array}$ & $\begin{array}{c}\text { Corr } \\
\text { With USA } \\
\end{array}$ & $\begin{array}{c}\text { LM } \\
\text { ARCH } \\
\end{array}$ \\
\hline S\&P 500 & 0.0058 & 0.0113 & 0.1441 & -0.1879 & 0.0467 & -0.7679 & 5.1381 & $\begin{array}{l}76.8098 \\
{[0.0000]} \\
\end{array}$ & --- & $\begin{array}{r}2094.664 \\
{[0.0000]} \\
\end{array}$ \\
\hline TSX & 0.0055 & 0.0112 & 0.1366 & -0.2178 & 0.0491 & -0.8836 & 5.6347 & $\begin{array}{l}111.5521 \\
{[0.0000]}\end{array}$ & 0.7581 & $\begin{array}{r}2524.420 \\
{[0.0000]} \\
\end{array}$ \\
\hline DAX 30 & 0.0039 & 0.0097 & 0.1264 & -0.1721 & 0.0565 & -0.7239 & 3.6330 & $\begin{array}{l}27.6754 \\
{[0.0000]} \\
\end{array}$ & 0.7502 & $\begin{array}{l}1717.540 \\
{[0.0000]} \\
\end{array}$ \\
\hline $\begin{array}{l}\text { All Ordinaries } \\
\text { Index }\end{array}$ & 0.0044 & 0.0088 & 0.0979 & -0.1408 & 0.0412 & -0.4863 & 3.2424 & $\begin{array}{l}11.1355 \\
{[0.0038]}\end{array}$ & 0.7014 & $\begin{array}{r}2977.530 \\
{[0.0000]} \\
\end{array}$ \\
\hline $\begin{array}{l}\text { KFX } \\
\text { Copenhagen } \\
\end{array}$ & 0.0065 & 0.0100 & 0.1778 & -0.2089 & 0.0550 & -0.6623 & 4.2482 & $\begin{array}{l}36.7153 \\
{[0.0000]} \\
\end{array}$ & 0.6508 & $\begin{array}{r}2730.840 \\
{[0.0000]} \\
\end{array}$ \\
\hline $\begin{array}{l}\text { Helsonki } \\
\text { General }\end{array}$ & 0.0059 & 0.0064 & 0.3050 & -0.3050 & 0.0899 & -0.1550 & 3.9711 & $\begin{array}{l}11.5174 \\
{[0.0032]}\end{array}$ & 0.5920 & $\begin{array}{l}1653.373 \\
{[0.0000]} \\
\end{array}$ \\
\hline $\begin{array}{l}\text { Madrid General } \\
\text { Index }\end{array}$ & 0.0034 & 0.0076 & 0.1503 & -0.1656 & 0.0555 & -0.5402 & 3.4424 & $\begin{array}{l}15.1076 \\
{[0.0005]}\end{array}$ & 0.7506 & $\begin{array}{l}2181.422 \\
{[0.0000]} \\
\end{array}$ \\
\hline CAC 40 & 0.0034 & 0.0076 & 0.1503 & -0.1656 & 0.0555 & -0.5402 & 3.4424 & $\begin{array}{l}15.1076 \\
{[0.0005]} \\
\end{array}$ & 0.7506 & $\begin{array}{l}2171.242 \\
{[0.0000]} \\
\end{array}$ \\
\hline FTSE 100 & 0.0039 & 0.0098 & 0.1192 & -0.1463 & 0.0451 & -0.5234 & 3.8179 & $\begin{array}{l}19.5583 \\
{[0.0001]}\end{array}$ & 0.8057 & $\begin{array}{l}1719.859 \\
{[0.0000]}\end{array}$ \\
\hline Milan MIB & 0.0008 & 0.0008 & 0.2103 & -0.1807 & 0.0645 & 0.0530 & 3.5618 & $\begin{array}{c}3.6225 \\
{[0.1635]}\end{array}$ & 0.6090 & $\begin{array}{l}1980.872 \\
{[0.0000]} \\
\end{array}$ \\
\hline Stockholm Index & 0.0063 & 0.0144 & 0.2487 & -0.1850 & 0.0685 & -0.2893 & 3.6164 & $\begin{array}{c}7.9225 \\
{[0.0190]} \\
\end{array}$ & 0.6577 & $\begin{array}{r}2304.311 \\
{[0.0000]} \\
\end{array}$ \\
\hline $\begin{array}{l}\text { Zurich Swiss } \\
\text { Market Index } \\
\end{array}$ & 0.0051 & 0.0129 & 0.1825 & -0.2028 & 0.0480 & -0.8209 & 5.5834 & $\begin{array}{l}103.8454 \\
{[0.0000]} \\
\end{array}$ & 0.7177 & $\begin{array}{r}2316.242 \\
{[0.0000]} \\
\end{array}$ \\
\hline $\begin{array}{l}\text { New Zealand } \\
\text { Stock Exchange } 50\end{array}$ & 0.0013 & 0.0039 & 0.1440 & -0.1922 & 0.0450 & -0.3840 & 4.3138 & $\begin{array}{l}25.6673 \\
{[0.0000]} \\
\end{array}$ & 0.5185 & $\begin{array}{r}2081.190 \\
{[0.0000]} \\
\end{array}$ \\
\hline Oslo Stock Index & 0.0058 & 0.0159 & 0.1658 & -0.3121 & 0.0698 & -1.1197 & 5.8562 & $\begin{array}{l}146.0017 \\
{[0.0000]} \\
\end{array}$ & 0.6589 & $\begin{array}{r}2242.252 \\
{[0.0000]} \\
\end{array}$ \\
\hline AEX & 0.0034 & 0.0100 & 0.1138 & -0.2558 & 0.0560 & -1.2546 & 6.1808 & $\begin{array}{l}181.9162 \\
{[0.0000]}\end{array}$ & 0.7816 & $\begin{array}{l}1911.685 \\
{[0.0000]}\end{array}$ \\
\hline Nikkei 225 & -0.0041 & -0.0011 & 0.1745 & -0.2443 & 0.0592 & -0.3770 & 4.6396 & $\begin{array}{l}36.0943 \\
{[0.0000]} \\
\end{array}$ & 0.4742 & $\begin{array}{r}413.0745 \\
{[0.0000]} \\
\end{array}$ \\
\hline ISEQ & 0.0032 & 0.0148 & 0.1809 & -0.2820 & 0.0673 & -1.0031 & 5.3738 & $\begin{array}{l}107.0630 \\
{[0.0000]}\end{array}$ & 0.7035 & $\begin{array}{l}2877.816 \\
{[0.0000]}\end{array}$ \\
\hline
\end{tabular}

Notes: We report the basic statistics of sample data over the period from 01/01/1990 to 01/05/2012. LM ARCH refers to the Lagrange Multiplier test for conditional heteroscedasticity to residuals with $q=5$. The associated probabilities are reported in brackets.

On the whole, the equity market returns distributions are typically non-normal and display volatility clustering (time-varying heteroscedasticity/GARCH effects) and fat tails (leptokurtosis).

Therefore, the stylized facts of the equity returns justify our choice of using GARCH processes to model their conditional volatility.

\section{Specification Tests And Model Estimation}

As a preliminary analysis and since we find the existence of GARCH effects in the statistical properties, a special focus on the GARCH models fitting to the asset return series is given to determine whether an asymmetric model is required, or whether the symmetric GARCH model is sufficient. There are two main categories: symmetric $(\mathrm{GARCH})$ and asymmetric (EGARCH, and GJR-GARCH). In the first category, the conditional variance only depends on the magnitude, and not on the sign of the asset, reflecting that volatility increases more after negative shocks than after positive ones of the same magnitude. In other words, a bad news generates higher volatility whereas a good news lowers the volatility. In contrast, these characteristics are more or less captured in the asymmetric models. 
We follow Engle and $\mathrm{Ng}$ (1993) who proposed a set of tests for asymmetry in volatility, known as sign bias tests, applied to the residuals of a GARCH fit to the returns data. The test for sign bias is based on the significance of ${ }_{1, i}$ for each market $i$ in:

$\hat{e}_{i, t}^{2}={ }_{0, i}+{ }_{1, i} S_{i, t 1}+{ }_{i, t}$

where $S_{i, t 1}=\begin{aligned} & 1 \text { if } \hat{\mathrm{e}}_{i, t 1}<0 \\ & 0 \text { otherwise }\end{aligned}$ and $\zeta_{i, t}$ is an independent and identically distributed error term.

If ${ }_{1, i}$ is statistically significant, it implies that positive and negative shocks to $\hat{e}_{i, t} 1$ impact differently upon the conditional variance. We carry out this test ${ }^{13}$ and find evidence of asymmetric volatility in all the return series. This is confirming the choice of GJR to model the volatility process.

Besides, we pay attention to the robustness of the parameters' estimation in the three-factor model since the hypothesis of normality is strongly rejected in our data. To overcome this issue, we use the Quasi-Maximum Likelihood Estimation (QMLE) method for a fat-tailed distribution and examine Student-t distribution and GED (Generalized Error Distribution). ${ }^{14}$ Preliminary, the simplex algorithm is used to initialize the process. Then, the estimation of the unknown parameters is carried out with a hill-climbing method using the algorithm $\mathrm{BHHH}^{15}$ or BFGS $^{16}$ developed respectively by Berndt et al. (1974), and Broyden (1970). The idea is that the simplex algorithm is used to refine initial estimates before using one of the derivative-based methods (BHHH or BFGS), which are more sensitive to the choice of initial estimates. This preliminary work is done to ensure the robustness of the estimation and the convergence of the model.

Our estimation process is carried out in three stages:

Firstly, we estimate, conditional on ${ }_{t}$, the vector of unknown parameters ${ }_{U S}={ }_{U S}^{\prime}$, US, US, US, US

in the system from Eq. (1) to Eq.(4) for the USA market. Secondly, based on the US estimates of stage 1, we examine the model for the different regions: Conditional on $t_{t 1}$ and $U_{S, t}$, we estimate the density function of the

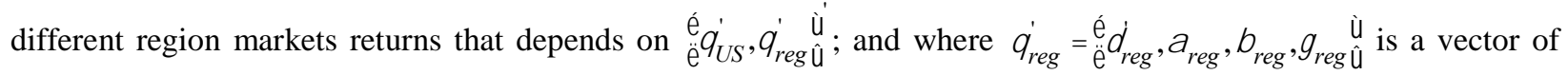
unknown parameters obtained by maximizing the likelihood function for the regional market returns in the system from Eq. (1) to Eq. (4). Thirdly, we estimate the system from Eq. (1) to Eq. (4) in a multivariate setting ${ }^{17}$ for all the markets, conditioning on the US and regional markets model estimations.

Before carrying out with the panel regressions, we, also, perform panel unit root tests in three stages to ensure that the idiosyncratic return shocks are stationary. The results are summarized in Table 2. We start by applying the first generation tests along the lines of Im, Pesaran, and Shin (2003), and Maddala and Wu (1999). Then, the second-generation panel unit root tests along the lines of Moon and Perron (2004), Choi (2002) and Pesaran (2003), which are based on the interdependencies between individuals, a crucial assumption in our analysis. And finally, Carrion-i-Silvestre (2005), a third-generation panel unit root test that takes into account the hypothesis of structural breaks in addition to that of the interdependencies.

\footnotetext{
${ }^{13}$ The results are available on request.

${ }^{14}$ Both the Student-t distribution and the GED have fat tails.

${ }^{15}$ Referring to the Berndt, Hausman, Hall and Hall.

${ }^{16}$ Referring to the Broyden, Fletcher, Goldfarb and Shanno.

${ }^{17}$ In a previous work, we followed Bekaert et al. (2005) and estimate the second and third steps in a univariate setting. However, a multivariate framework seems to be more realistic when considering relationships between return series.
} 
Given the results of panel unit root tests, we conclude after the first two tests (without dependencies and structural breaks of Im, Pesaran, and Shin (2003), and Maddala and Wu (1999)), that our model series are stationary. When applying the tests of second and third generations, the assumption of stationarity is also confirmed. This denotes that the first generation tests, themselves, are sufficiently robust to take into account the existence of interdependencies and structural breaks in our data. All the tests lead to reject the presence of unit root. This is a necessary condition in our panel analysis.

Table 2: Unit Root Tests ${ }^{18}$

\begin{tabular}{|c|c|c|c|}
\hline Tests & Statistic & $e_{i}$ & $e_{r e g}$ \\
\hline \multicolumn{4}{|l|}{ First Generation Tests } \\
\hline Im, Pesaran and Shin (2003) & $\begin{array}{l}W_{\text {tbar }} \\
Z_{\text {tbar }}\end{array}$ & $\begin{array}{c}-56,078 \\
(0.00) \\
-53,477 \\
(0.00) \\
\end{array}$ & $\begin{array}{c}-66,692 \\
(0.00) \\
-63,288 \\
(0.00) \\
\end{array}$ \\
\hline Maddala and Wu (1999) & $\begin{array}{l}P_{M W} \\
Z_{M W}\end{array}$ & $\begin{array}{c}138,155 \\
(<0.01) \\
13,962 \\
(0.00) \\
\end{array}$ & $\begin{array}{c}147,365 \\
(<0.01) \\
14,420 \\
(0.00) \\
\end{array}$ \\
\hline \multicolumn{4}{|l|}{ Second Generation Tests } \\
\hline Moon and Perron (2004) & $\begin{array}{l}t_{a} \\
t_{b} \\
t_{a}^{*} \\
t_{b}^{*}\end{array}$ & $\begin{array}{c}-493,325 \\
(0.00) \\
-42,345 \\
(0.00) \\
-488,097 \\
(0.00) \\
-42,420 \\
(0.00)\end{array}$ & $\begin{array}{c}-618,293 \\
(0.00) \\
-55,266 \\
(0.00) \\
-620,079 \\
(0.00) \\
-55,757 \\
(0.00)\end{array}$ \\
\hline Choi (2002) & $\begin{array}{c}P_{m} \\
Z \\
L^{*}\end{array}$ & $\begin{array}{c}31,798 \\
(0.00) \\
-14,403 \\
(0.00) \\
-19,666 \\
(0.00)\end{array}$ & $\begin{array}{c}32,841 \\
(0.00) \\
-14,876 \\
(0.00) \\
-20,311 \\
(0.00)\end{array}$ \\
\hline Pesaran (2003) & CIPS & $\begin{array}{r}-5,834 \\
(0.01)\end{array}$ & $\begin{array}{r}-6,143 \\
(0.01)\end{array}$ \\
\hline Moon and Perron (2004) & $\begin{array}{c}t_{a} \\
t_{b} \\
t_{a}^{*} \\
t_{b}^{*}\end{array}$ & $\begin{array}{c}-493,325 \\
(0.00) \\
-42,345 \\
(0.00) \\
-488,097 \\
(0.00) \\
-42,420 \\
(0.00)\end{array}$ & $\begin{array}{c}-618,293 \\
(0.00) \\
-55,266 \\
(0.00) \\
-620,079 \\
(0.00) \\
-55,757 \\
(0.00)\end{array}$ \\
\hline Choi (2002) & $\begin{array}{l}P_{m} \\
Z \\
L^{*}\end{array}$ & $\begin{array}{c}31,798 \\
(0.00) \\
-14,403 \\
(0.00) \\
-19,666 \\
(0.00)\end{array}$ & $\begin{array}{c}32,841 \\
(0.00) \\
-14,876 \\
(0.00) \\
-20,311 \\
(0.00)\end{array}$ \\
\hline Pesaran (2003) & $C I P S^{*}$ & $\begin{array}{c}-5,834 \\
(0.01) \\
\end{array}$ & $\begin{array}{l}-6,143 \\
(0.01)\end{array}$ \\
\hline \multicolumn{4}{|l|}{ Third Generation Test } \\
\hline Carrion-i-Silvestre (2005) & $\operatorname{LM}(\quad)$ & $\begin{array}{c}0.719 \\
(0.236) \\
{[4.079]}\end{array}$ & $\begin{array}{c}0.712 \\
(0.238) \\
{[3.808]}\end{array}$ \\
\hline
\end{tabular}

Note: Numbers in parentheses are the standard deviations, and the associated probabilities are reported in brackets.

\footnotetext{
${ }^{18}$ We consider the tests for a model with a trend.
} 


\section{RESULTS}

\section{Cross-Patterns Co-Movements During The Whole Period}

We report on Table 3 the average betas, correlations, and variance ratios for all the countries. We remind that our ICAPM produces time-varying betas, correlations, and variance ratios, but we only report the sample average of these conditional variables. This analysis is necessary in our study to highlight interdependencies levels between equity markets within the region and thus the consequences of decisions taken by private governments/ investors. While correlation coefficients between world markets (Hamao et al., 1990, and Tse, 2000) spillovers in means and spillovers in variances (Edwards, 1998; Forbes and Rigobon, 2002; McAleer and Nam, 2005) have been established, we concentrate our attention on OECD equity markets. Our main interest is to track the stability of the OECD equity markets.

First, let us focus on the estimated coefficients ${ }_{i}^{\stackrel{4}{u} \text { and }}{ }^{{ }^{\wedge}}{ }_{i}^{\text {reg }}$ that measure the OECD equity markets' sensitivities to global and regional risks, respectively. For Canada, which represents with the USA the North America region, the beta with respect to the USA market is positive of 0.717 . In the whole sample, Canada has the highest beta's value. This denotes that the closest country to the USA is the most sensitive one, which seems to be a realistic finding. If we move to the Asian equity markets, the betas with respect to the USA market factor are positive and significant, too, varying between 0.404 and 0.592 respectively for New-Zealand and Japan, denoting that the Asian region is sensitive to what happens in the US. The betas with respect to the Asian-Pacific region factor are also positive and significant, varying between 0.270 to 1.004 respectively for Japan and New-Zealand. This denotes that Japan and New-Zealand may be impacted both by the USA and regional markets. Therefore, the US and the Asian-pacific factors do account in the Asian return shocks.

Concerning the European region, the betas with respect to the US market are positive and relatively high, ranging from 0.185 for France to 0.911 for Finland. Betas with respect to the regional market (the European index) are positive and highest, reaching 1.353 for Sweden for instance. Then, we analyze the correlations and variances ratios. For Canada, the correlation with the US market is positive, significant, and the highest one. The relative proportion of conditional return variance that is accounted by the U.S. is also the highest one. The results for the Asian-Pacific markets correlations are more pronounced with the USA than with the regional factor. For instance Australia is the most correlated with the USA $(51.1 \%)$ and surprisingly negatively correlated with the Asian region with $-50.9 \%$. Japan is more positively correlated with the USA market $(32.5 \%)$ than with the Asian-Pacific region with $24.2 \%$. The same feature is for New-Zealand with a correlation of $46.9 \%$ and $12.1 \%$ respectively with the US and regional factors, respectively.

Our results confirm those of other empirical studies. For example, Ratanapakon and Sharma (2002) and Lim et al. (2003) showed that Asian markets are partially integrated regionally. Also, Siklos and Ng (2001) showed the existence of strong interdependencies between the Asian markets and the US one. Still in the Asian-Pacific region, the amount of variance explained by the US market is more pronounced than the one explained by the AsianPacific region. To give some values, $12.1 \%, 28.3 \%$ and $23.8 \%$ are the conditional return variances respectively for Japan, Australia and New-Zealand and can be attributed to USA shocks. In contrast, the amounts of variance of those countries explained by the Asian-Pacific region are very low and respectively $0.5 \%, 1.6 \%$ and $1.1 \%$. 
Table 3: Betas, Correlations, and Variance Ratios

\begin{tabular}{|c|c|c|c|c|c|c|}
\hline Country & ${ }_{i}^{\wedge}$ & ${ }_{i}^{r e g}$ & $V \hat{R}_{i}^{u s}$ & $V \hat{R}_{i}^{r e g}$ & ^us & $\stackrel{i e g}{i}$ \\
\hline \multicolumn{7}{|c|}{ North America Region } \\
\hline Canada & $\begin{array}{c}0.717 \\
(0.051)\end{array}$ & $\begin{array}{c}0.756 \\
(0.047)\end{array}$ & $\begin{array}{c}0.348 \\
(0.167)\end{array}$ & --- & $\begin{array}{c}0.574 \\
(0.137)\end{array}$ & --- \\
\hline \multicolumn{7}{|c|}{ Asian-Pacific Region } \\
\hline Japan & $\begin{array}{c}0.592 \\
(0.101)\end{array}$ & $\begin{array}{c}1.004 \\
(0.001)\end{array}$ & $\begin{array}{c}0.121 \\
(0.100)\end{array}$ & $\begin{array}{c}0.005 \\
(0.003)\end{array}$ & $\begin{array}{c}0.325 \\
(0.124)\end{array}$ & $\begin{array}{c}0.242 \\
(0.066)\end{array}$ \\
\hline Australia & $\begin{array}{c}0.503 \\
(0.113) \\
\end{array}$ & $\begin{array}{l}0.288 \\
(0.09) \\
\end{array}$ & $\begin{array}{c}0.283 \\
(0.165) \\
\end{array}$ & $\begin{array}{c}0.016 \\
(0.006) \\
\end{array}$ & $\begin{array}{c}0.511 \\
(0.149) \\
\end{array}$ & $\begin{array}{c}-0.509 \\
(0.199)\end{array}$ \\
\hline New-Zealand & $\begin{array}{c}0.404 \\
(0.130) \\
\end{array}$ & $\begin{array}{c}0.270 \\
(0.107) \\
\end{array}$ & $\begin{array}{c}0.238 \\
(0.142) \\
\end{array}$ & $\begin{array}{c}0.011 \\
(0.008)\end{array}$ & $\begin{array}{c}0.469 \\
(0.133) \\
\end{array}$ & $\begin{array}{c}0.121 \\
(0.043)\end{array}$ \\
\hline \multicolumn{7}{|l|}{ European Region } \\
\hline UK & $\begin{array}{c}0.636 \\
(0.042) \\
\end{array}$ & $\begin{array}{c}0.874 \\
(0.030)\end{array}$ & $\begin{array}{c}0.005 \\
(0.000)\end{array}$ & $\begin{array}{c}0.972 \\
(0.009) \\
\end{array}$ & $\begin{array}{c}0.007 \\
(0.002)\end{array}$ & $\begin{array}{c}0.142 \\
(0.039) \\
\end{array}$ \\
\hline Norway & $\begin{array}{c}0.816 \\
(0.112) \\
\end{array}$ & $\begin{array}{c}1.166 \\
(0.095) \\
\end{array}$ & $\begin{array}{c}0.002 \\
(0.003) \\
\end{array}$ & $\begin{array}{c}0.005 \\
(0.005)\end{array}$ & $\begin{array}{c}0.045 \\
(0.021)\end{array}$ & $\begin{array}{c}0.084 \\
(0.038)\end{array}$ \\
\hline Sweden & $\begin{array}{c}0.864 \\
(0.162)\end{array}$ & $\begin{array}{c}1.353 \\
(0.153)\end{array}$ & $\begin{array}{c}0.002 \\
(0.003)\end{array}$ & $\begin{array}{c}0.018 \\
(0.009)\end{array}$ & $\begin{array}{c}0.043 \\
(0.020)\end{array}$ & $\begin{array}{c}0.163 \\
(0.045)\end{array}$ \\
\hline Switzerland & $\begin{array}{c}0.553 \\
(0.068) \\
\end{array}$ & $\begin{array}{c}0.752 \\
(0.060) \\
\end{array}$ & $\begin{array}{c}0.002 \\
(0.002) \\
\end{array}$ & $\begin{array}{c}0.007 \\
(0.007) \\
\end{array}$ & $\begin{array}{c}0.039 \\
(0.019) \\
\end{array}$ & $\begin{array}{c}0.079 \\
(0.031) \\
\end{array}$ \\
\hline Denmark & $\begin{array}{c}0.574 \\
(0.102)\end{array}$ & $\begin{array}{c}0.875 \\
(0.080)\end{array}$ & $\begin{array}{c}0.002 \\
(0.002)\end{array}$ & $\begin{array}{c}0.013 \\
(0.009)\end{array}$ & $\begin{array}{c}0.040 \\
(0.019)\end{array}$ & $\begin{array}{c}0.021 \\
(0.020)\end{array}$ \\
\hline Finland & $\begin{array}{c}0.911 \\
(0.233)\end{array}$ & $\begin{array}{c}1.221 \\
(0.285)\end{array}$ & $\begin{array}{c}0.002 \\
(0.002)\end{array}$ & $\begin{array}{c}0.009 \\
(0.006)\end{array}$ & $\begin{array}{c}0.046 \\
(0.019)\end{array}$ & $\begin{array}{c}0.093 \\
(0.028)\end{array}$ \\
\hline France & $\begin{array}{c}0.185 \\
(0.139)\end{array}$ & $\begin{array}{c}0.883 \\
(0.115)\end{array}$ & $\begin{array}{c}0.001 \\
(0.000)\end{array}$ & $\begin{array}{c}0.026 \\
(0.024)\end{array}$ & $\begin{array}{c}0.017 \\
(0.008)\end{array}$ & $\begin{array}{c}0.174 \\
(0.051) \\
\end{array}$ \\
\hline Germany & $\begin{array}{c}0.724 \\
(0.125)\end{array}$ & $\begin{array}{c}0.940 \\
(0.146)\end{array}$ & $\begin{array}{c}0.002 \\
(0.002)\end{array}$ & $\begin{array}{c}0.019 \\
(0.011)\end{array}$ & $\begin{array}{c}0.041 \\
(0.018)\end{array}$ & $\begin{array}{c}0.162 \\
(0.057)\end{array}$ \\
\hline Spain & $\begin{array}{c}0.702 \\
(0.076)\end{array}$ & $\begin{array}{c}0.964 \\
(0.078)\end{array}$ & $\begin{array}{c}0.002 \\
(0.002)\end{array}$ & $\begin{array}{c}0.024 \\
(0.015)\end{array}$ & $\begin{array}{c}0.042 \\
(0.019)\end{array}$ & $\begin{array}{c}0.172 \\
(0.050)\end{array}$ \\
\hline Ireland & $\begin{array}{c}0.825 \\
(0.189)\end{array}$ & $\begin{array}{c}0.818 \\
(0.216)\end{array}$ & $\begin{array}{c}0.001 \\
(0.001)\end{array}$ & $\begin{array}{c}0.029 \\
(0.013)\end{array}$ & $\begin{array}{c}0.030 \\
(0.009)\end{array}$ & $\begin{array}{c}0.214 \\
(0.072)\end{array}$ \\
\hline Italy & $\begin{array}{c}0.677 \\
(0.123)\end{array}$ & $\begin{array}{c}1.108 \\
(0.131)\end{array}$ & $\begin{array}{c}0.001 \\
(0.001)\end{array}$ & $\begin{array}{c}0.027 \\
(0.017)\end{array}$ & $\begin{array}{c}0.035 \\
(0.015)\end{array}$ & $\begin{array}{c}0.210 \\
(0.076)\end{array}$ \\
\hline Netherlands & $\begin{array}{c}0.716 \\
(0.071)\end{array}$ & $\begin{array}{c}0.868 \\
(0.081)\end{array}$ & $\begin{array}{c}0.002 \\
(0.003)\end{array}$ & $\begin{array}{c}0.031 \\
(0.013)\end{array}$ & $\begin{array}{c}0.045 \\
(0.021)\end{array}$ & $\begin{array}{c}0.203 \\
(0.055)\end{array}$ \\
\hline
\end{tabular}

Note: Numbers in parentheses are the standard deviations.

Surprisingly, the regional factor does not account for very much of the total variation of return shocks in Asia. If we move to the European region, the correlations with respect to the USA market are significant and positive; however, surprisingly, they are very low (not exceeding $0.5 \%$ ). The correlations with the regional market (the European index) are low, but, in all cases, larger than the ones with the USA market and more pronounced for some countries than for others. In fact, for Ireland, the correlation is $21.4 \%$ while it is $2.1 \%$ for Denmark. Fratzscher (2002) and Hardouvelis et al. (2006) showed an increase in European market integration. This increase in correlations over time may result from increased volatility and/ or any change in cross-country linkages. Forbes and Rigobon (2002) show that higher volatility in one country's stock market will automatically increase the unconditional correlation in returns with another country. If volatility in one country increases, even if the transmission mechanism between the two countries is constant, a larger share of the return in the second country will be driven by the larger, idiosyncratic shocks in the first country.

The relative proportion of conditional return variance that is accounted for by the U.S. is low because of the higher idiosyncratic volatility of these markets. This finding is in line with the one of Bekaert et al. (2005). The fraction of the return shock variance explained by the USA factor is small, ranging from $0.5 \%$ to $1 \%$. Also, the regional market does not explain a large amount of total shock variance, with the exception being UK (97.20\%). 
These results on betas, correlation and variance ratios give us a taste about the behavior of OECD equity markets towards the global and regional risks, and are in line with what we would expect, given the relative idiosyncratic nature of various markets.

According to our findings, we, first, remark that the country-specific beta parameter ( $\left.\begin{array}{c}u s \\ i\end{array}{ }^{u r} \quad \begin{array}{l}r e g \\ i\end{array}\right)$ is positive, denoting that higher volatility in the USA market, or regional one may affect market $i$. Second, we note that the return volatility of market $i$ is positively related to the conditional variances of the USA and regional markets with differences across countries. There appears to be potential asymmetric effects in the USA or regional markets that induce asymmetry in the conditional return volatility of any equity market. However, these crosspatterns capture co-movements between markets during crises as well as normal events. Therefore, although the results in this section document trends in interdependence over time, this does not necessarily capture contagion. So after investigating patterns in regional and global factors, we move to test contagion effects. We consider three crises: the Asian crisis, the ERM crisis, and the Subprime-Global financial one.

\section{Contagion Effects}

The correlation detected in the previous section itself is not evidence of contagion. We are interested in the time-series patterns during calm/ turmoil events. To study contagion effects, we use a panel regression of the country's idiosyncratic shocks onto a country-specific constant, and both global and regional residuals whose slope coefficients are allowed to change both in calm and turbulent periods.

We estimate the model described by Eq. (11)-(12), using panel data for each group of countries. We consider three groups: North America, Asia-Pacific and Europe, and test the significance of parameters $p_{i}$ and $q_{i} \quad i=1,2$. Significant increases of correlations between residuals are signs of contagion. We test the existence of contagion during three specific periods: the ERM (1992:07 - 1993:12), the Asian crisis (1997:04 - 1998:10) and the subprime/ global financial crisis (2007:07 - 2013:11). For clearness, $D_{i, t}^{1,1}$ and $D_{i, t}^{1,2}$ denote for respectively tranquil time and subprime crisis in the USA market. While, $D_{i, t}^{2,1}$ and $D_{i, t}^{2,2}$ represent both calm and turmoil periods in the different regional markets. The coefficients $q_{1}$ and $q_{2}$ measure the increase in residuals correlations of the different OECD equity markets respectively with the benchmark (USA) and regional markets during crisis periods. While, the coefficients $p_{1}$ and $p_{2}$ account for the additional residuals correlation of the different OECD equity markets respectively with the benchmark (USA) and regional markets during calm times. Therefore, test for the existence of contagion over the entire period for the USA market (respectively, for the region) amounts to testing the null hypothesis of joint coefficients $p_{i}$ and $q_{i}, H_{0}: p_{1}=q_{1}=0$ (respectively $H_{0}: p_{2}=q_{2}=0$ ). Moreover, understanding the channels through which shocks are transmitted across countries (global or regional factors risks) is the key issue for policymakers hoping to mitigate any negative effects. The baseline tests of contagion from the panel model are reported on Table 4.

We start by the $p_{1}$ coefficient that measures the additional correlation of the OECD country's idiosyncratic shocks with the USA idiosyncratic shocks during the USA normal period. $p_{1}$ is positive, being exceptions of Sweden, Switzerland and New-Zealand, suggesting that the idiosyncratic residuals are better correlated with the USA even in a tranquil period. This confirms that the USA retains its place of world's leader. 
Table 4: Cross-Section Analysis Of OECD Idiosyncratic Shocks USA and Regional Return Residuals

\begin{tabular}{|c|c|c|c|c|c|c|c|}
\hline \multirow[b]{2}{*}{ Country } & \multicolumn{5}{|c|}{ Coefficients } & \multicolumn{2}{|c|}{ Wald Test } \\
\hline & $p_{1}$ & $q_{1}$ & $p_{2}$ & $q_{2}$ & Constant & $p_{1}=q_{1}=0$ & $p_{2}=q_{2}=0$ \\
\hline North America & $\begin{array}{c}0.0046 \\
(0.0490)\end{array}$ & $\begin{array}{c}0.2071 \\
(0.1415)\end{array}$ & --- & --- & $\begin{array}{c}-0.010 * \\
(0.002)\end{array}$ & $\begin{array}{c}2.043 \\
{[0.874]}\end{array}$ & --- \\
\hline Europe & $\begin{array}{l}-0.0655 \\
(0.0446)\end{array}$ & $\begin{array}{l}0.1618^{*} \\
(0.0296)\end{array}$ & $\begin{array}{c}-0.0155 \\
(0.132)\end{array}$ & $\begin{array}{c}-0.0642 * * \\
(0.0303)\end{array}$ & $\begin{array}{l}-0.022^{*} \\
(0.001)\end{array}$ & $\begin{array}{c}25.987 \\
{[<0.001]}\end{array}$ & $\begin{array}{c}0.833 \\
{[0.825]}\end{array}$ \\
\hline UK & $\begin{array}{l}0.0789 \\
(0.062)\end{array}$ & $\begin{array}{l}0.1503^{*} \\
(0.0243)\end{array}$ & $\begin{array}{c}-0.1076^{* *} \\
(0.061)\end{array}$ & $\begin{array}{l}0.4489 * \\
(0.2117)\end{array}$ & $\begin{array}{l}-0.024 * \\
(0.0028)\end{array}$ & $\begin{array}{c}6.286 \\
{[0.043]}\end{array}$ & $\begin{array}{c}79.49 \\
{[<0.001]}\end{array}$ \\
\hline Norway & $\begin{array}{c}0.0865 \\
(0.1208)\end{array}$ & $\begin{array}{c}0.1141 \\
(0.0803)\end{array}$ & $\begin{array}{c}-0.1950 * * * \\
(0.0995)\end{array}$ & $\begin{array}{c}0.0397 \\
(0.3088)\end{array}$ & $\begin{array}{l}-0.025^{*} \\
(0.0036)\end{array}$ & $\begin{array}{c}2.827 \\
{[0.243]}\end{array}$ & $\begin{array}{c}0.854 \\
{[0.836]}\end{array}$ \\
\hline Sweden & $\begin{array}{c}-0.1042 \\
(0.123)\end{array}$ & $\begin{array}{l}0.0720 \\
(0.082)\end{array}$ & $\begin{array}{l}-0.0966 \\
(0.1025)\end{array}$ & $\begin{array}{l}0.9778^{*} \\
(0.3175)\end{array}$ & $\begin{array}{l}-0.021 * \\
(0.0037)\end{array}$ & $\begin{array}{c}20.09 \\
{[<0.001]}\end{array}$ & $\begin{array}{c}2.523 \\
{[0.772]}\end{array}$ \\
\hline Switzerland & $\begin{array}{l}-0.0161 \\
(0.1015)\end{array}$ & $\begin{array}{c}-0.0265^{*} \\
(0.0028)\end{array}$ & $\begin{array}{c}-0.1466 * * * \\
(0.0819)\end{array}$ & $\begin{array}{c}-0.1976 \\
(0.2606)\end{array}$ & $\begin{array}{l}-0.026^{*} \\
(0.0028)\end{array}$ & $\begin{array}{c}26.456 \\
{[<0.001]}\end{array}$ & $\begin{array}{c}2.063 \\
{[0.84]}\end{array}$ \\
\hline Denmark & $\begin{array}{c}0.1379 \\
(0.1071)\end{array}$ & $\begin{array}{c}0.1285^{* * * *} \\
(0.0712)\end{array}$ & $\begin{array}{c}-0.2950^{*} \\
(0.08)\end{array}$ & $\begin{array}{c}0.2471 \\
(0.2404)\end{array}$ & $\begin{array}{l}-0.024^{*} \\
(0.0031)\end{array}$ & $\begin{array}{c}38.833 \\
{[<0.001]}\end{array}$ & $\begin{array}{c}1.489 \\
{[0.472]}\end{array}$ \\
\hline Finland & $\begin{array}{c}0.0152 \\
(0.1575)\end{array}$ & $\begin{array}{c}0.1140 \\
(0.1047)\end{array}$ & $\begin{array}{c}-0.2091 \\
(0.1801)\end{array}$ & $\begin{array}{c}0.9780 * * * \\
(0.5877)\end{array}$ & $\begin{array}{c}-0.018^{*} \\
(0.005)\end{array}$ & $\begin{array}{c}79.459 \\
{[<0.001]}\end{array}$ & $\begin{array}{c}3.526 \\
{[0.832]}\end{array}$ \\
\hline France & $\begin{array}{c}0.0585 \\
(0.0841)\end{array}$ & $\begin{array}{l}0.1445^{*} \\
(0.0437)\end{array}$ & $\begin{array}{c}0.0321 \\
(0.4635)\end{array}$ & $\begin{array}{c}0.0761 \\
(0.0923)\end{array}$ & $\begin{array}{l}-0.020^{*} \\
(0.004)\end{array}$ & $\begin{array}{r}20.011 \\
{[0.002]}\end{array}$ & $\begin{array}{l}2.341 \\
{[0.93]}\end{array}$ \\
\hline Germany & $\begin{array}{c}0.1214 * \\
(0.038)\end{array}$ & $\begin{array}{l}0.1515^{*} \\
(0.0701)\end{array}$ & $\begin{array}{c}-0.2403^{*} \\
(0.0779)\end{array}$ & $\begin{array}{c}0.0901 * * * \\
(0.049)\end{array}$ & $\begin{array}{c}-0.020^{*} \\
(0.003)\end{array}$ & $\begin{array}{c}26.456 \\
{[<0.001]}\end{array}$ & $\begin{array}{c}38.586 \\
{[<0.001]}\end{array}$ \\
\hline Spain & $\begin{array}{c}0.0853 \\
(0.1051)\end{array}$ & $\begin{array}{c}0.1363 \\
(0.0696)\end{array}$ & $\begin{array}{l}-0.0882 \\
(0.1122)\end{array}$ & $\begin{array}{c}0.0418 * * * \\
(0.0229)\end{array}$ & $\begin{array}{c}-0.021^{*} \\
(0.003)\end{array}$ & $\begin{array}{c}4.749 \\
{[0.093]}\end{array}$ & $\begin{array}{c}0.211 \\
{[0.004]}\end{array}$ \\
\hline Ireland & $\begin{array}{c}0.3824 * \\
(0.07)\end{array}$ & $\begin{array}{l}0.5862 * \\
(0.1048)\end{array}$ & $\begin{array}{l}-0.3032^{*} \\
(0.1022)\end{array}$ & $\begin{array}{c}0.1284 \\
(0.4207)\end{array}$ & $\begin{array}{c}-0.025^{*} \\
(0.003)\end{array}$ & $\begin{array}{c}2.827 \\
{[0.243]}\end{array}$ & $\begin{array}{c}2.365 \\
{[0.812]}\end{array}$ \\
\hline Italy & $\begin{array}{c}0.1234 \\
(0.1210)\end{array}$ & $\begin{array}{c}0.1395^{* * * *} \\
(0.0804)\end{array}$ & $\begin{array}{c}-0.2131 * * \\
(0.1013)\end{array}$ & $\begin{array}{c}0.7851 * * \\
(0.3611)\end{array}$ & $\begin{array}{l}-0.022^{*} \\
(0.003)\end{array}$ & $\begin{array}{c}14.703 \\
{[0.095]}\end{array}$ & $\begin{array}{c}65.256 \\
{[<0.001]}\end{array}$ \\
\hline Netherlands & $\begin{array}{l}0.1873 * \\
(0.0654)\end{array}$ & $\begin{array}{l}0.2348^{*} \\
(0.0986)\end{array}$ & $\begin{array}{c}-0.2689^{*} \\
(0.0693)\end{array}$ & $\begin{array}{c}0.0570 \\
(0.3015)\end{array}$ & $\begin{array}{c}-0.021^{*} \\
(0.003)\end{array}$ & $\begin{array}{c}0.309 \\
{[0.857]}\end{array}$ & $\begin{array}{c}47.258 \\
{[<0.001]}\end{array}$ \\
\hline Asia-Pacific & $\begin{array}{l}-0.0687 \\
(0.0746)\end{array}$ & $\begin{array}{l}0.1395^{*} \\
(0.0494)\end{array}$ & $\begin{array}{l}-0.0188 \\
(0.1252)\end{array}$ & $\begin{array}{c}0.0493 \\
(0.0409)\end{array}$ & $\begin{array}{l}-0.007 * \\
(<0.001)\end{array}$ & $\begin{array}{c}6.484 \\
{[0.039]}\end{array}$ & $\begin{array}{c}3.241 \\
{[0.666]}\end{array}$ \\
\hline Japan & $\begin{array}{l}0.2852 * \\
(0.0751)\end{array}$ & $\begin{array}{c}0.2912 * * \\
(0.1144)\end{array}$ & $\begin{array}{c}0.0692 \\
(0.1336)\end{array}$ & $\begin{array}{c}0.1522 \\
(0.3827)\end{array}$ & $\begin{array}{l}0.0003 \\
(0.003)\end{array}$ & $\begin{array}{c}11.29 \\
{[0.004]}\end{array}$ & $\begin{array}{l}0.510 \\
{[0.91]}\end{array}$ \\
\hline Australia & $\begin{array}{c}0.0803 * * * \\
(0.0486)\end{array}$ & $\begin{array}{c}0.1047 * \\
(0.073)\end{array}$ & $\begin{array}{l}-0.1332 \\
(0.1482)\end{array}$ & $\begin{array}{c}0.1266 \\
(0.4528)\end{array}$ & $\begin{array}{c}-0.014^{*} \\
(0.002)\end{array}$ & $\begin{array}{c}1.306 \\
{[0.52]}\end{array}$ & $\begin{array}{c}4.521 \\
{[0.882]}\end{array}$ \\
\hline New Zealand & $\begin{array}{l}-0.0743 \\
(0.0613)\end{array}$ & $\begin{array}{c}-0.2418^{*} \\
(0.091)\end{array}$ & $\begin{array}{l}-0.0389 \\
(0.2573)\end{array}$ & $\begin{array}{l}0.191 \\
(0.49)\end{array}$ & $\begin{array}{c}-0.013^{*} \\
(0.003)\end{array}$ & $\begin{array}{c}0.422 \\
{[0.81]}\end{array}$ & $\begin{array}{c}3.634 \\
{[0.689]}\end{array}$ \\
\hline
\end{tabular}

Notes: Numbers in parentheses are the standard deviations and the ones in brackets are Wald-test p-values. * significative to $1 \%$, ** significative to $5 \%, * * *$ significative to $10 \%$

The correlation with respect to the USA is significantly higher for most European countries but with different magnitudes. Differences in vulnerability to contagion, especially in the Eurozone, are remarkable.

For instance, in Europe, the correlation with the USA for Ireland is the highest one with 0.3824 followed by that of Japan with 0.2852 , for the Asian-Pacific region. This is due to the relation of the financial institutions with the USA. It is well know that for instance international companies like Apple, Amazon, and eBay are notable Irish companies but have subsidiaries in the US. Not only, Toyota, Fujifilm, and Panasonic are examples of very famous Japan companies.

Moreover, the coefficient $q_{1}$, measuring the additional correlation of the country's idiosyncratic shocks with the USA during the subprime/ global financial crisis period, is positive, indicating that residuals have become more correlated during the subprime crisis. The highest increase is that of Ireland with 0.5862 followed by that of Japan with 0.2912. This coefficient is negative only for Switzerland and New-Zealand. The hypothesis of no contagion over the entire period, $H_{0}: p_{1}=q_{1}=0$, for the USA, can be rejected for most OECD markets. Instead, 
this hypothesis is strongly rejected for Europe, exceptions being of Ireland and Norway, and for New-Zealand and Australia, when considering Asian-Pacific region. Only Japan seems to be significantly impacted by the subprime/ global financial crisis. However, for Canada, this hypothesis is accepted denoting that even though Canada is the nearest country to the USA, it has not been impacted by the subprime and the global financial crises. What is noticeable is that contagion effects from the US on OECD countries exist both in calm and turbulent times; however, contagion is higher in crisis period than in calm one.

For the coefficient $p_{2}$, in eight out of twelve European equity markets, the correlation with the regional residuals is significant. This suggests that, even in a calm period, any idiosyncratic shock in the European region is transmitted to most of its countries. However, this is not the case for the Asian-Pacific countries.

Focusing on the coefficient $q_{2}$, we find that the correlation jumps highly especially during the ERM crisis for Finland and Sweden with respectively 0.978 and 0.9778 followed by Italy with 0.7851 . Besides, the UK reaches a significant and important value of 0.4489 . However, for the Asian crisis, the correlations with the Asian region are insignificant indicating no contagion during the Asian crisis for Japan, Australia and New-Zealand. So signs of transmission effects exist between the European Union and the USA and may be due to globalization and may be explained by international trade that may play a role as a transmission channel in the spread of shocks. [Manasse and Zavalloni (2012)].

Besides, we carry out the joint Wald test to determine whether $H_{0}: p_{2}=q_{2}=0$ denotes regional overall contagion or not? During the Asian crisis, the joint Wald test $p_{2}=q_{2}=0$ is not rejected at the level of $5 \%$. This indicates that there is no regional contagion during the Asian crisis. This may be unexpected result but may be explained by the fact that we include in the Asian-Pacific region only Australia, Japan and New-Zealand. However this finding was confirmed by Forbes and Rigobon (2001) who conclude that only interdependencies exist. Also, in Europe, the joint test suggests that the UK, Germany, Spain, Italy and the Netherlands are significantly impacted by the ERM crisis.

Our results have important implications both for researchers and market players. Generally, the high levels of interdependence in global equity markets do not concern policymakers, except during periods of contagion when an extreme negative shock in one country affects others.

\section{CONCLUSION}

This paper studies interdependence and contagion across OECD countries during the period 1990-2013 using an empirical approach. To this aim, we consider a dynamic three-factor model, including local, global and regional factor. It allows us to extract the idiosyncratic shocks to be used in a contagion analysis. In fact, we consider that the co-movements part is explained by the common sources of risk, economic fundamentals to focus on cross-patterns. And the other part of idiosyncratic co-movements is studied in a panel model to test potential contagion effects. Contagion is tested as a significant excess correlation, both in USA and regional factors, among the model residuals during normal and crisis periods. We were interested to the case of three main crises : the Asian crisis, the ERM one and the subprime/ global financial crisis. Our framework allows for time-varying expected returns as well as time-varying risk loadings for OECD equity markets both in crisis and non-crisis periods.

Our exploratory results suggest that: first, the idiosyncratic residuals are better correlated with the US, even in a tranquil period. This confirms that the USA retains its place of world's leader. Second, the additional correlation of the country's idiosyncratic shocks with the USA during the subprime/ global financial crisis period is positive indicating that residuals have become more correlated during the subprime crisis. Third, the hypothesis of no contagion over the entire period, for the US, can be rejected for most OECD markets. Besides, in Europe, Germany, the UK, the Netherlands, Spain and Italy are significantly impacted by the ERM crisis. However, during the Asian crisis, there is no regional contagion during the Asian crisis. Our results are interesting and are in line with those of Dungey and Martin (2001), Bekaert et al. (2005), Hsien-Yi (2012), and Bouaziz et al. (2012). In a further paper, we are comparing our results using a linear methodology with those obtained from a nonlinear approach. 


\section{AUTHOR INFORMATION}

Olfa Kaabia, INSEEC Lab, INSIGNIS Business School, Paris, France. E-mail: okaabia@inseec.com

\section{REFERENCES}

1. Acharya, Viral V., Drechsler, I., and Schnabl, P. (2011). "A Pyrrhic victory? - Bank Bailouts and Sovereign Credit Risk". NBER Working Paper N 17136, National Bureau of Economic Research.

2. Adler, M., and Dumas, B. (1983). "International portfolio selection and corporation finance: A synthesis". Journal of Finance vol 38, pp.925-984.

3. $\quad$ Allen, F., Babus, A. and Carletti, E. (2012). "Asset Commonality, Debt Maturity and Systemic Risk." Journal of Financial Economics, vol. 104(3), pages 519-534.

4. Allen, F., and Carletti, E. (2006). "Credit Risk Transfer and Contagion." Journal of Monetary Economics, vol 53, pp. 89-111.

5. Almeida, H., Campello, M., Laranjeira, B. and Weisbenner, S. (2012). "Corporate debt maturity and the real effects of the 2007 credit crisis", Critical Finance Review 1, 3-58.

6. Bagliano, F. C., and Morana, C. (2012). "The Great Recession: US Dynamics and Spillovers to the World Economy". Journal of Banking and Finance, vol. 36(1), pages 1-13.

7. Bekaert, G., and Harvey, C. R. (1997). "Emerging equity market volatility". Journal of Financial Economics, vol. 43, pages 29-77.

8. Bekaert, G., Harvey, C. R., and Ng A. (2005). "Market integration and contagion". Journal of Business. 78:1, 39-69.

9. Bekaert, G., and Wu, G. (2000). "Asymmetric volatility and risk in equity markets". Review of Financial Studies, vol. 13, pages 1-42.

10. Bekaert, G., Ehrmann, M., Fratzscher, M. and Mehl, A.J. (2011). "Global Crises and Equity Market Contagion", NBER Working Papers 17121, National Bureau of Economic Research, Inc.

11. Beltratti, A., and Stulz, R. M. (2012). "The credit crisis around the globe: Why did some banks perform better?", Journal of Financial Economics 105, 1-17.

12. Berndt, E.R., Hall, B.H., and Hausman, J.A. (1974). "Estimation and Inference in Nonlinear Structural Mosdels", Anals of Economic and Social Measurement, 3, pp. 653-666.

13. Billio, M., and Pelizzon, L. (2003). "Volatility and Shocks Spillover Before and After EMU in European Stock Markets," Journal of Multinational Financial Management, 13, 323-340.

14. Bollerslev, T. (1986). "Generalized Autoregressive Conditional Heteroskedasticity", Journal of Econometrics, 31, 307-327.

15. Bollerslev, T. and Wooldridge J.M. (1992). "Quasi-maximum likelihood estimation and inference in dynamic models with time-varying covariances", Econometric Reviews, 1, 143-173.

16. Bouaziz, M., Selmi, N., and Boujelbene, Y. (2012). "Contagion Effect of The Subprime Financial Crisis: Evidence of DCC Multivariate GARCH Models". European Journal of Economics, Finance and Administrative Sciences, ISSN 1450-2275 Issue 44.

17. Boyer, B.H., Gibson, M.S., and Loretan, M. (1999). "Pitfalls in Tests for Changes in International Finance", Discussion Papers, $N^{\circ}$ 597, Board of Governors of the Federal Reserve Board.

18. Broyden, C. G. (1970). "The convergence of single-rank quasi-Newton methods". Math. Comp., 24:365382.

19. Calomiris, C., Love, I. and Martinez Peria, M. S. (2012). "Stock returns' sensitivities to crisis shocks: Evidence from developed and emerging markets", Journal of International Money and Finance 31, 743765 .

20. Carrieri, F., Errunza, V. and Hogan, K. (2007). "Characterizing world market integration through time", Journal of Financial and Quantitative Analysis, 42, 915-941.

21. Carrion-i-Silverstre, J. L. (2005). "Health care expenditure and GDP: are they broken stationary?", Journal of Health Economics, 24, 5, 939-854.

22. Carrasco, M. and Chen, X. (1999). "B-mixing and moment properties of various GARCH, stochastic volatility and ACD models", London School of Economics, Working Paper.

23. Chiang, T.C., Jeon, B.N. and Li., H. (2007). "Dynamic correlation analysis of financial contagion: Evidence from Asian markets," Journal of International Money and Finance, vol. 26(7), pages 1206-1228. 
24. Choi, I. (2002). "Combination Unit Root Tests for Cross-Sectionally Correlated Panels", Mimeo, Hong Kong University of Science and Technology.

25. Chen, N., and Zhang, F. (1997). "Correlations, trades and stock returns of the Pacific rim markets". Pacific Basin Finance Journal, vol. 5, pages 559-77.

26. Claessen, S. and Forbes, K. (2001). "International Financial Contagion", Kluwer Academic Publisher.

27. Claessens, S., Djankov, S., J. Fan, and Lang, L. (2002). "Disentangling the incentive and entrenchment effects of large shareholdings". Journal of Finance, 57, 2741-2771.

28. Corsetti, G., Kuester, K., Meier, A., and G. J. Muller. (2012). "Sovereign risk, fiscal policy, and macroeconomic stability". IMF Working paper 12/33.

29. Corsetti F., Pericoli M. and Sbracia, M. (2005). "Some Contagion, Some Interdependence: More Pitfalls in Tests for Financial Contagion." Journal of International Money and Finance, vol. 24(8), pages 1177-1199.

30. Diebold, F. and Yilmaz, Y. (2012). "Better to Given than to Receive: Predictive Directional Measurement of Volatility Spillovers". International Journal of Forecasting, 28, p.57-66.

31. Dumas, B., Solnik, B. (1995). "The world price of foreign exchange risk". Journal of Finance 50, $445-479$.

32. Dungey M. and Zhumabekova D. (2001). "Testing for contagion using correlation: some words of caution", Pacific Basin Working Paper Series, Working Paper n PB01-09.

33. Dungey, M., Fry, R.A., Gonzalez-Hermisillo, B. and Martin, V.L. (2003). "Empirical Modelling of Contagion: A Review of Methodologies", mimeo, ANU and CERF.

34. Dungey, M., Martin, V.L. (2007). "Unravelling financial market linkages during crises", Journal of Applied Econometrics, vol. 22, pages 89-119.

35. Dungey, M., Milunovich, G., Thorp, S. (2010). "Unobservable shocks as carriers of contagion. Journal of Banking and Finance", vol. 34, pages 1008-1021.

36. Dungey, M., Fry, R., Gonzalez-Hermosillo, B. and Martin, V. (2011). "Transmission of Financial Crises: A Latent Factor Approach". Oxford University Press, New York.

37. Edwards, S. (1998). "Interest Rate Volatility, Contagion and Convergence: an Empirical Investigation of the Cases of Argentina, Chile and Mexico". Journal of Applied Economics, 1 (1), 55-86.

38. Engle, R. (1982). "Autoregressive Conditional Heteroskedasticity with Estimates of the Variance of United Kingdom Inflation". Econometrica, 50:987-1007.

39. Engle, R. F., and Ng, V. K. (1993). "Time-Varying Volatility and the Dynamic Behavior of the Term Structure", Journal of Money, Credit and Banking, Blackwell Publishing, vol. 25(3), pages 336-49, August.

40. $\quad$ Eichengreen B., Rose A.K., Wyplosz, C. (1996). "Contagious currency crises. Scandinavian", Journal of Economics, vol. 98(4), pages 463-484.

41. Eichengreen, B., Mody, A., Nedeljkovic, M., and Sarno, L. (2012). "How the subprime crisis went global: Evidence from bank credit default swap spreads", Journal of International Money and Finance 31, 12991318.

42. Ehrmann, M., and Fratzscher, M. (2003). "Interdependence between the Euro area and the USA: what role for EMU?," Proceedings, Board of Governors of the Federal Reserve System (US).

43. Favero, C., and Giavazzi, F. (2002). "Is the international propagation of financial shocks nonlinear? Evidence from the ERM." Journal of International Economics, vol. 57, pages 231-46.

44. Forbes, K. (2012). "The "Big C": Identifying Contagion, " NBER Working Papers 18465, National Bureau of Economic Research, Inc.

45. Forbes, K. and Rigobon, R. (2002). "No Contagion, Only Interdependence: Measuring Stock Market Comovements." Journal of Finance, vol. 57(5), pages 2223-2261.

46. Forbes, K. and Rigobon, R. (2000). "Contagion in Latin America: definitions, measurement, and policy Implications". Economica 1, n², pages 1-46.

47. Forni, M., M. Hallin, M. Lippi, and L. Reichlin (2003). "Do Financial Variables Help Forecasting Inflation and Real Activity in the Euro Area?", Journal of Monetary Economics, vol. 50, pages 1243-55.

48. Frankel, J., and Saravelos, G. (2010). "Are leading indicators of financial crises useful for assessing country vulnerability? Evidence from the 2008-09 Global Crisis", NBER Working Paper 16047.

49. Fratzscher, M. (2002). "Financial Market Integration in Europe: on the Effect of EMU on Stock Markets," International Journal of Finance and Economics, 7(3), pp. 165-194.

50. $\quad$ Fratzscher, M. (2003). "On Currency Crises and Contagion." International Journal of Finance and Economics, vol. 8(2), pages 109-129. 
51. Glick, R., and Rose, A. K. (1999). "Contagion and Trade: Why Are Currency Crises Regional", Journal of International Money and Finance, vol. 18(4), pages 603-618.

52. Glosten, L. R., Jaganathan, R. and Runkle, D. E. (1993). "On the relation between the expected value and the volatility of the nominal excess return on stocks", Journal of Finance 48, 1779-1801.

53. Gourieroux, C., Monfort, A. (1989). "Statistics and Econometric Models", (vol.1). Cambridge: Cambridge University Press.

54. Guo, F., Chen, C.R., and Huang, Y.S. (2011). "Markets contagion during financial crisis: A regimeswitching approach". International Review of Economics and Finance, Vol. 20, 95-109

55. Greenwood, R., Landier, A. and Thesmar, D. (2011). "Vulnerable Banks." TSE Working Paper 11-280, Toulouse School of Economics, November 2011.

56. Hamao, Y.R., Masulis, R.W., and Ng., V.K. (1990). "Correlations in Price Changes and Volatility Across International Stock Markets", Review of Financial Studies, vol 3 p. 281-307.

57. Hau, H., and Lai, S. (2012). "The role of equity funds in the financial crisis propagation", CEPR Discussion Paper 8819, Centre for Economic Policy Research.

58. Hardouvelis, G. M., and Priestley, D. (2006). "EMU and Stock Market Integration", Journal of Business, vol. 79, pages 365-392.

59. Hsien-Yi, L. (2012). "Contagion in International Stock Markets during the Sub Prime Mortgage Crisis", International Journal of Economics and Financial Issues, Econjournals, vol. 2(1), pages 41-53.

60. Im, K.S., Pesaran, M.H. and Shin, Y. (2003). "Testing for Unit Roots in Heterogeneous Panels", Journal of Econometrics, 115, 1, 53-74.

61. Jang, H., and Sul, W. (2002). "The Asian financial crisis and the co-movement of Asian stock markets". Journal of Asian Economics, vol. 13, pages 94-104.

62. Jarque, C. M., and Bera, A. K. (1987). "A test for normality of observations and regression residuals". International Statistical Review, vol. 55, pages 163-172.

63. Johansson, A.C. (2011). "Financial Markets in East Asia and Europe during the Global Financial Crisis". The World Economy, 2011, 1088-1105.

64. Kaabia, O. and Abid, I., (2013), "Theoretical Channels of International Transmission during the Subprime Crisis to OECD Countries: A FAVAR Model under Bayesian Framework", Journal of Applied Business Research, Vol. 29(2) 443-460.

65. Kaminsky, G. and Reinhart, C. (2001). "On Crises, Contagion and Confusion", Journal of International Economics, vol. 51(1), pages 145-168.

66. Lim, K., H. Lee and Liew, K. (2003). "International diversification benefits in Asian stock markets: a revisit". Mimeo, Lebuan School of International Business and Finance, Universiti Malasya Sabbah y Faculty of Economics and Management, University Putera Malaysia.

67. Kenourgios, D., Samitas, A., and Paltalidis, N. (2011). "Financial crises and stock market contagion in a multivariate time-varying asymmetric framework". Journal of International Financial Markets, Institutions and Money, Vol. 21, 92-106.

68. King, M., Wadhwani, S. (1990). "Transmission of volatility between stock markets". Review of Financial Studies, 3, 5-33.

69. King M, Sentana, E., and Wadhwani S. (1994). "Volatility and links between national stock markets". Econometrica, vol. 62, pages 901-933.

70. Longin, F. and Solnik B. (1995). "Is the International Correlation of Equity Returns Constant: 19601990?". Journal of International Money and Finance, February, 3-26.

71. Longstaff, F.A. (2010). "The subprime credit crisis and contagion in financial markets". Journal of Financial Economics, vol. 97, pages 436-450.

72. Longstaff, F.A., and Ang, A. (2011). "Systemic Sovereign Credit Risk: Lessons from the USA and Europe", NBER Working Paper 16892, National Bureau of Economic Research, Inc.

73. Maddala, G.S. et Wu, S. (1999). "A Comparative Study of Unit Root Tests with Panel Data and a New Simple Test", Oxford Bulletin of Economics and Statistics, special issue, 631-652. Manasse, P. and Zavalloni, L. (2012). "Sovereign Contagion in Europe: Evidence from the CDS Market", DSE Working Paper $n^{\circ} 863$.

74. McAleer, M., Nam, J.C. (2005). "Testing for Contagion in Asian Exchange Rates" Mathematics and Computers in Simulation, 68, 519-527. 
75. Mishkin, F. (2011). "Over the cliff: From the subprime to the Global Financial Crisis". Journal of Economic Perspectives, vol. 25, pages 49-70.

76. Moon, H. R. and Perron, B. (2004). "Testing for a Unit Root in Panels with Dynamic Factors", Journal of Econometrics, 122, 81-126.

77. Moussalli, C.B. (2007). "Financial Crises, Panic and Contagion: Evidence from a Cross-country Comparison Using Two Time Frames", Business and Public Affairs, vol.1 (2): 1-17.

78. Nagayasu, J. (2000). "Currency Crisis and Contagion: Evidence from Exchange Rates and Sectoral Stock Indices of the Philippines and Thailand", Working Paper No.00/39, IMF.

79. Neaime, S. (2012). "The global financial crisis, financial linkages and correlations in returns and volatilities in emerging MENA stock markets". Emerging Markets Review, 268-282.

80. Ng, A. (2000). "Volatility Spillover Effects from Japan and the US to the Pacific Basin", Journal of International Money and Finance, Vol. 19, pp. 207-233.

81. Pesaran, H.M. (2003). "A Simple Panel Unit Root Test in the Presence of Cross Section Dependence", Mimeo, University of Southern California.

82. Pesaran, M. H. and Pick, A. (2007). "Econometric Issues in the Analysis of Contagion". Journal of Economics Dynamics and Control, vol. 31(4), pages 1245-1277.

83. Phylaktis, K., Xia, L. (2006). "Sources of firms' industry and country effects in emerging markets", Journal of International Money and Finance, vol. 25, pages 459-475.

84. Pindyck, R.S., and Rotemberg, J.J. (1990). "The excess co-movement of commodity prices". Economic Journal, 100, 1173-89.

85. Pindyck, R. S., and Rotemberg, J. J. (1983). "Dynamic factor demands and the effects of energy price shocks". American Economic Review, 73, 1066-1079.

86. Rose, A., and Spiegel, M. (2010). "Cross-country causes and consequences of the 2008 crisis: International linkages and American exposure", Pacific Economic Review 15, 340-363.

87. Rose, A., and Spiegel, M. (2011). "Cross-country causes and consequences of the crisis: An update", European Economic Review 55, 309-324.

88. Ratanapakon, O., and Sharma, S. (2002). "Interrelationships among regional stock indices". Review of Financial Economics, 11, 91-108.

89. Rigobon, R. (1999). "On the measurement of the international propagation of shocks". Working paper 7354, National Bureau of Economic Research, Cambridge, MA.

90. Shin, H.S. (2012). "Global Banking Glut and Loan Risk Premium." IMF Economic Review 60, n 2, pp. 155-192.

91. Siklos, P.L., and Ng, P. (2001). "Integration among Asia-Pacific and international stock markets: common stochastic trends and regime shifts", Pacific Economic Review, 6, 89-110.

92. Tai, C. (2007). "Market Integration and Currency Risk in Asian Emerging Markets", Research in International Business and Finance, 21(1), pp. 98-117.

93. Taylor, S.J. (1986). "Modeling Financial Time Series". Chichester, UK: John Wiley and Sons.

94. Tong, H., and Wei, S-J. (2010). "The misfortune of non-financial firms in a financial crisis: Disentangling finance and demand shocks, in Wealth, Financial Intermediation and the Real Economy", National Bureau of Economic Research.

95. Tong, Hui, and Wei, S-J. (2011). "The composition matters: Capital inflows and liquidity crunch during a global economic crisis", Review of Financial Studies 24, 2023-2052.

96. Tse, Y.K. (2000). "A Test for Constant Correlations in a Multivariate GARCH model". Journal of Econometrics, 98 (1), 107-127.

97. Tse, Y. K. and Tsui, A.K.C. (2002). "A Multivariate Generalized Autoregressive Conditional Heteroscedasticity Model with Time-Varying Correlations," Journal of Business \& Economic Statistics, American Statistical Association, vol. 20(3), pages 351-62, July.

98. Van Wincoop, E. (2011). "International Financial Contagion Through Leveraged Financial Institutions". NBER Working Paper No. 17686, National Bureau of Economic Research. 